\title{
Adalékok a közszolgálati jog jogágiságának kérdéséhez
}

\author{
Additional Remarks on the Question of Civil Service Law \\ as a Branch of Law
}

\begin{abstract}
ABSZTRAKT
A tanulmány fókuszában a közszolgálati jog és a munkajog viszonyának vizsgálata áll. Magyarországon az elmúlt szük egy évtizedben jelentős változások következtek be a közszolgálati jogviszonyok szabályozásában. A közszolgálati jogviszonyok száma gyarapodott, az ezzel összefüggő jogviták elbírásának fórumrendszere és eljárási szabályai is megváltoztak, a közalkalmazotti jogállásban állók száma pedig gyors fogyásnak indult. Mindez azért bír különös jelentöséggel, mert a jogágak létére meghatározó befolyást gyakorol a jogalkotás is. A tanulmány következtetése szerint azt, hogy a közszolgálati jog valóban képes lesz-e önállósulni, nem „belső” fejlődés fogja eredményezni, hanem a jogalkotói törekvések.
\end{abstract}

Kulcsszavak: jogág, jogterület, közszolgálati jog, közszolgálati jogviszony, munkajog

\begin{abstract}
The study focuses on the relationship between civil service law and labour law. In Hungary, there have been significant changes in the last decade regarding the regulation of civil service law. The types of the civil service legal relationships have increased, the forums and procedural rules for adjudicating civil service law related disputes have changed, and the number of public employees providing public services has rapidly decreased. This is of particular importance because the existence of these branches of the law is determined by legislation as well. The study concludes that the ability of civil service law to become an independent branch of law will be determined not by 'internal' developments but by legislative ambitions.
\end{abstract}

Keywords: branch of law, field of law, civil service law, legal status of public servants, labour law

Immáron hét éve, hogy a közszolgálati jog önállóságát vizsgálva egy tanulmány - amelynek jelen tanulmány szerzői közül ketten szerzői voltak - arra a megállapításra jutott, hogy a közszolgálati jog nem önálló jogág, hanem a munkajog részét képező speciális jogterület. ${ }^{1}$ Következtetései értelmében nem indokolt a magánmunkajog és a közszolgálati jog mesterséges szétválasztása, a közszolgálati jog mint jogterület

\footnotetext{
* Dr. Horváth István, egyetemi docens, Eötvös Loránd Tudományegyetem Állam- és Jogtudományi Kar, Munkajogi és Szociális Jogi Tanszék, e-mail: horvath.istvan@ajk.elte.hu; ügyvéd, Dr. P. Horváth Ügyvédi Iroda, Budapest. Dr. Kun Attila, egyetemi tanár, Károli Gáspár Református Egyetem Állam- és Jogtudományi Kar, Munkajogi és Szociális Jogi Tanszék, e-mail: kun.attila@kre.hu; egyetemi tanár, Nemzeti Közszolgálati Egyetem Államtudományi és Nemzetközi Tanulmányok Kar, Emberi Erőforrás Tanszék, e-mail: Kun.Attila@uni-nke.hu; Dr. Petrovics Zoltán, egyetemi adjunktus, Eötvös Loránd Tudományegyetem Állam- és Jogtudományi Kar, Munkajogi és Szociális Jogi Tanszék, e-mail: petrovics.zoltan@ajk.elte.hu; Nemzeti Közszolgálati Egyetem
} 
a munkajog részének tekintendő. ${ }^{2}$ A szabályozás túlnyomórészt kógens módszere ellenére - amely a munkajog diszpozitív karakterétől alapvető eltérést jelentő különbség - a szabályozott életviszonyok hasonlósága miatt nem lehet azt elszakítottan kezelni a munkajogtól. Mindezekre tekintettel a tanulmány szerint helyesebbnek tűnik az egységes munkajogon belül megkülönböztetni a magánmunkajog és a közszolgálati jog területét, amely egyszerre összetartozik és különbözik is. ${ }^{3}$

A hivatkozott tanulmányban írottak érvényessége megítélésünk szerint nem veszített a jelentőségéből, az abban foglalt megállapítások továbbra is irányadóak. Ettől függetlenül azonban megállapítható az is, hogy időközben valami mégis megváltozott: az azóta eltelt szük egy évtized alatt a jogalkotó nagyobb sebességre kapcsolva növelte a közszolgálati jogviszonyok ${ }^{4}$ és az azokat szabályozó törvények (és rendeletek) számát.

Ez azért bír különös jelentőséggel, mert valamennyi jogág vagy jogterület, így a munkajog és a közszolgálati jog jogrendszerbeli elhelyezése végső soron jogalkotói vagy politikai döntés függvénye (is). Egy adott időszakban megszilárdult jogági tagozódás idővel változhat. A változás nem feltétlenül jogdogmatikai dilemmák megoldásából, a jogrendszer „belső” fejlődéséből következik, hanem az állami beavatkozás - amelynek magától értetődő eszköze a jogalkotás - hatására következik be, mögötte pedig gyakran (jog)politikai akarat húzódik meg. ${ }^{5}$

Mindezek a körülmények éppen ezért nem hagyhatók figyelmen kívül a közszolgálati jog önállóságának vizsgálata során sem. Különösen szembetűnő ugyanis, hogy az elmúlt évtized közszolgálati joggal összefüggő jogalkotási fejleményeinek jelentős része markánsan a közszolgálati jog önállósága irányába mutat. Ez akkor sem hagyható figyelmen kívül, ha a jogági besorolásnak lényegét tekintve a jogtudományelméleti szempontok mellett elsődlegesen az egyetemi oktatás tekintetében van különös jelentősége. Ezen túlmenően az elmúlt években a tudományos diskurzus is foglalkozott a problémával, olyan érveket is felsorakoztatva, amelyek a közszolgálati jog önállóságát hangsúlyozták.

Államtudományi és Nemzetközi Tanulmányok Kar, Emberi Erőforrás Tanszék, e-mail: Petrovics.Zoltan@uninke.hu; orcid.org/0000-0001-5683-3624.

${ }^{1}$ Kun Attila-PETRovics Zoltán: A közszolgálati jog önálló jogági fejlődésének kérdéséről. Magyar Közlöny Lapés Könyvkiadó, Budapest, 2014.

2 ZACCARIA Márton Leó: Egy „keresztülfekvő” jogág jellemzői - értekezés a magyar munkajog dogmatikai sajátosságairól. Glossa luridica, 2011/1, 120-121., MÉLYPATAKI Gábor: Változó közszolgálati dogmatika az új közszolgálati törvény fényében. Új Magyar Közigazgatás, 2012/4, 64.

${ }^{3}$ Lásd ezzel ellentétes, a közszolgálati jog önálló, munkajogtól elkülönülő jogágként történő definiálására: ÁRVA Zsuzsanna-BALÁzs István-BARTA Attila-VESZPRÉMı Bernadett: Közigazgatás-elmélet. Debreceni Egyetemi Kiadó, Debrecen, 2017, 122-123., BALÁzs István: A közszolgálati rendszerek átalakulásának egyes jellemzői napjainkban. In: Auer Ádám-Berke Gyula-György István-Hazafi Zoltán (szerk.): Ünnepi kötet a 65 éves Kiss György tiszteletére. Liber Amicorum in honorem Georgii Kiss aetatis suae LXV. Dialóg Campus, Budapest, 2018, 59.

${ }^{4}$ E körben a „közszolgálati jogviszonyok” kifejezést általánosságban használjuk a közszolgálati jog területéhez tartozó jogviszonyok megjelölésére.

${ }^{5}$ Mélypataki Gáborral és Prugberger Tamással párhuzamosan arra a következtetésre juthatunk, hogy a közszolgálati jog mint önálló jogág léte jelen pillanatban inkább ideológiai és politikai, mintsem feszes dogmatikai alapokon nyugszik. MÉLYPATAKI Gábor-PRUGBERGER Tamás: A közszolgálat fogalmának és dogmatikájának átalakulása. Közjogi Szemle, 2021/1, 15. 
Mindezeken túlmenően az elmúlt évek változásainak áttekintésére az is ösztönzött bennünket, hogy 2018. január 1-töl a közszolgálati jogviszonnyal kapcsolatos jogviták már nem munkaügyi perben, hanem közigazgatási perben kerülnek elbírálásra, ezen túlmenően az elmúlt években hatályba lépő közszolgálati törvények is egyre intenzívebben közvetítik a közszolgálati jogviszonyok munkaviszonyoktól történő elkülönítésére irányuló szilárd politikai akaratot.

A fentiek összességében megítélésünk szerint elegendő okot szolgáltatnak arra, hogy e fejlemények fényében ismét értékeljük a közszolgálati jog önállóságának kérdését, oly módon, hogy lehetőség szerint kerüljük el a hivatkozott tanulmány érvelésének megismétlését, $s$ csupán a fentiekben felvetett jelenségekkel foglalkozzunk - reflektálva azokra.

\section{A közszolgálati jog önállósága melletti újabb érvek a tudományos diskurzusban}

A fentiekben hivatkozott tanulmányban 6 írottakkal vitába szállva György István a közszolgálati jog és a munkajog önálló jogágisága mellett foglal állást. A jogrendszer közjogra és magánjogra tagozódását alapul véve megállapítja, hogy „logikailag tarthatatlannak látszik azon állitás, amely szerint a közszolgálati jog - bármilyen mértékben és módon - a munkajog része lehetne. Két különbözö, nagy halmazba (közjog, magánjog) tartozó jogág, jogterület vagy akár elkülönülten szabályozott magatartáscsoport (hívjuk egyelőre bárminek) közül az egyik nem tartozhat a másik halmazba sorolható jogágba." György István álláspontja szerint azon túlmenően, hogy mindkét terület a más részére végzett függő vagy önállótlan munkavégzést szabályozza, három tényező tekintetében alapvető különbséget mutat: az ellátandó munka típusa (az egyik közérdeket, a másik magánérdeket szolgál), a szolgálatadó minősége (állami vagy önkormányzati, vagy ilyen tulajdonban lévő szerv, amely állami impériummal rendelkezik versus magánjogi jogalany), valamint a szolgálatadók autoritása nyomán a munkavégzők állampolgárokkal való kapcsolatának jellege (jogok és kötelezettségek különbözőségei, kényszerítő eszközök igénybevételének lehetősége az egyik, míg hiánya a másik oldalon). ${ }^{8}$ Ezt az érvelést kiegészíti azzal, hogy a közszolgálati alkalmazott a szolgálatot élethivatásként gyakorolja és fokozott felelősséggel rendelkezik, a közszolgálati jog pedig „kógens jogi normákat alkalmaz, amelyek szigorú alá-fölérendeltségi, egyoldalú, személytelen viszonyokat hoznak létre az alanyok között”. ${ }^{9}$ Ezen érvek alapján György István szerint „a közszolgálati jog a jogrendszer közjogba tartozó, elkülönült, önálló jogága”.10

${ }^{6}$ Kun-PETROVICS: i. m.

${ }^{7}$ GYÖRGY István: Munkajog, a munka közjoga vagy közszolgálati jog? In: Auer Ádám-Berke Gyula-György István-Hazafi Zoltán (szerk.): Ünnepi kötet a 65 éves Kiss György tiszteletére. Liber Amicorum in honorem Georgii Kiss aetatis suae LXV. Dialóg Campus, Budapest, 2018, 268. [a továbbiakban: GYöRGY (2018)].

8 GYÖRGY (2018): i. m., 270., 274.

9 GYÖRGY (2018): i. m., 274.

10 GYÖRGY (2018): i. m., 274. 
A magunk részéröl - nem megismételve a hivatkozott tanulmány által a közjog és a magánjog elválasztásának viszonylagosságáról írottakat ${ }^{11}$ - nem tartjuk kizártnak, hogy a közszolgálati jogot is magában foglaló munkajog egyszerre magán viselje a közjog és a magánjog jegyeit is. Voltaképpen ez a munkajog keretében - annak érdemi kialakulásától kezdve - mindig is így volt, jelenleg is így van. A magánmunkajog ugyanis nem alkalmaz tisztán diszpozitív módszert, az általa szabályozott életviszonyok pedig közjogi kötődéssel is rendelkeznek, ${ }^{12}$ ily módon abban eleve keverednek magánjogias és közjogias elemek is. ${ }^{13}$

Balázs István szintén vitatja a munkajog és a közszolgálati jog együvé tartozását. Amint kifejti, az álláspont, miszerint a közszolgálati jog a munkajog részét képező jogterület, magyarázatot ad a közszolgálati életpályareform közigazgatási jogtudományi megközelítésének hiányára. Úgy ítéli meg, hogy e következtetés azon törekvést támasztja alá, hogy a közszolgálatban „a viszonylag nagy életpálya-garanciákat jelentő, a szakmai érdemekre alapozott, zárt, karrierrendszerü szabályozást feladva a munkajogias megközelítés érvényesüljön". ${ }^{14} \mathrm{~A}$ helyzet ezzel szemben megítélésünk szerint valójában az, hogy azon állítás, miszerint a közszolgálati jog része a munkajognak, aligha volt hatással, de talán pontosabb akként fogalmazni, hogy semmilyen hatással nem bírt a közszolgálati életpálya utóbbi évtizedben végbemenő reformjára, illetve reformjaira. Ha ugyanis e következtetést, annak indokait és érvrendszerét a jogalkotó akárcsak részben is elfogadta volna, feltehetö, hogy a közszolgálati jogi szabályozás ma kevésbé lenne differenciált, nem született volna új jogállási törvény a kormánytisztviselőkre vagy a különleges jogállású szervek köztisztviselöire nézve, a közalkalmazotti jogállás nem apadna folyamatosan, és a közszolgálati jogviszonnyal összefüggő pereket még ma is a (közigazgatási és) munkaügyi bíróság bírálná el. Ezen túlmenően megjegyzendő, hogy a közszolgálati jognak a munkajog területén belüli elhelyezése egy további nem elhanyagolható ",haszonnal” is jár(na): a munkajogi logikából épphogy szükségképpen következnének a magánjogias és közjogias karakterű, a szolgálatvállaló védelmét biztosító kiegyensúlyozó mechanizmusok, és ilyen módon mindezek képesek lennének erősíteni a közszolgálatban az úgynevezett életpálya-garanciákat is. Ezzel ellentétben éppen a közjogi logikából - mint kiindulópontból - következhet a szolgálatvállaló szinte feltétlen „alávetettsége” és a garanciák, kiegyensúlyozó mechanizmusok háttérbe szorítása. Megítélésünk szerint az, hogy a közszolgálati jog a munkajog speciális jogterülete, nem zárja ki a közszolgálati jogviszonyok sajátos, garanciákkal körülbástyázott, nagyobb stabilitást nyújtó, és szakmai érdemekre alapozott zárt, karrierrendszerủ szabályozását, amit egyébként magunk is helyesnek tartanánk. Megjegyzést érdemel, hogy - „belülről nézve” - maga a munkajog is eleve differenciált, sokrétű (lásd az

\footnotetext{
11 Kun-Petrovics: i. m., 8-11.

12 Lásd például a kollektív munkajog egyes intézményeit, a munkavédelem szabályozását vagy a foglalkoztatás állami felügyeletére vonatkozó rendelkezéseket.

13 Kun-Petrovics: i. m., 16.

${ }^{14}$ BALÁzs István: A jogtudomány helye, szerepe, haszna a közigazgatási jogtudomány szemszögéböl. MTA Law Working Papers, 2015/25, Magyar Tudományos Akadémia, Budapest, 2015, 12. https://jog.tk.mta.hu/ uploads/files/mtalwp/2015_25_Balazs.pdf (2021. 05. 26.).
} 
atipikus munkaviszonyok ${ }^{15}$ egyre bővülö körét). ${ }^{16}$ Semmi nem zárja ki, hogy annak (védelmi) „ernyője” alatt kerüljenek sajátos szabályozásra a közszolgálati munkaviszonyok is.

\section{A közszolgálati jogi szabályozás újabb tendenciái}

A rendszerváltást követően Magyarországon 1992. július 1-jével vált külön a közszféra és a magánszféra munkajogi szabályozása. Az úgynevezett trichotóm struktúrájú szabályozásban a versenyszféra munkajogi szabályait a Munka Törvénykönyvéröl szóló 1992. évi XXII. törvény (a továbbiakban: 1992. évi Mt.) rögzítette, míg a köztisztviselökre a köztisztviselők jogállásáról szóló 1992. évi XXIII. törvény (a továbbiakban: Ktv.), valamint a közalkalmazottakra pedig a közalkalmazottak jogállásáról szóló 1992. évi XXXIII. törvény (a továbbiakban: Kjt.) rendelkezéseit kellett alkalmazni. A civil közszolgálat duplikált szabályozását 2010-ben a kormánytisztviselők jogállásáról szóló 2010. évi LVIII. törvény (a továbbiakban: Ktjv.) törte meg, amely kiemelte a Ktv. hatálya alól a kormánynak alárendelt közigazgatási szerveknél foglalkoztatottakat.

Újabb jelentős változás történt 2012-ben, amikor hatályba lépett a közszolgálati tisztviselökről szóló 2011. évi CXCIX. törvény (a továbbiakban: Kttv.), ezzel párhuzamosan hatályon kívül helyezésre került a Ktv. és a Ktjv. Annak ellenére, hogy a versenyszféra munkajogi kódexe nem maradt általános háttérjogszabálya a Kttv.-nek, így a közszolgálati tisztviselőkröl önálló és egységes normaanyag rendelkezett, a törvény figyelemmel volt a munkajogi szabályozásra, részben szó szerint is átvéve annak egyes rendelkezéseit. ${ }^{17}$

A jogalkotó ugyanakkor már 2016-ban feladta azt az elképzelést, hogy akár csak a civil közszolgálat területén önálló és egységes normaanyag rendelkezzen a közszolgálati tisztviselökröl, ugyanis 2016. július 1-jén hatályba lépett az állami tisztviselökröl szóló 2016. évi LII. törvény (a továbbiakban: Áttv.), amely egy új jogviszony, az állami szolgálati jogiszony segítségével leválasztotta a kormánytisztviselők csoportjáról a kormányhivatalok, valamint a járási hivatalok állami tisztviselőit és állami ügykezelöit. A különböző jogállási törvények széttartása ettől kezdődően azáltal is felerősödött, hogy az Áttv. a nyílt (egyben a magánmunkajogi megoldások iránt fogékonyabb, egyúttal a közjogi logikát is erősítő) közszolgálati jogi szabályozás irányába tett jelentős lépéseket, különösen az illetményrendszer tekintetében. ${ }^{18}$ Annak ellenére azonban, hogy a jogalkotó eredetileg - előbb 2018., majd 2019. január 1-jei

${ }^{15}$ Lásd Non-standard employment around the world: Understanding challenges, shaping prospects. International Labour Office, Geneva, 2016. https://www.ilo.org/global/publications/books/WCMS_534326/lang--en/ index.htm (2021. 05. 31.).

${ }^{16}$ Közte például: a köztulajdonban álló munkáltatóval fennálló munkaviszony.

17 Lásd a közszolgálati tisztviselők jogállásáról szóló 2011. évi CXCIX. törvény Általános Indokolását.

${ }^{18}$ HAZAFI Zoltán: A Magyary Program egységes közszolgálati életpályamodelljének értelmezése. In: Kiss György (szerk.): Közszolgálati életpályák jogi szabályozása. Dialóg Campus, Budapest, 2019, 44. 
hatállyal - az Áttv.-t kívánta kiterjeszteni a központi államigazgatási szervekre is, ez a lépés végül elmaradt. ${ }^{19}$

Ezt követően a civil közszolgálat szabályozása ismét új irányt vett, a jogalkotó ugyanis egyidejüleg döntött az Áttv. 2018. december 31-i hatályon kívül helyezéséről, valamint a kormányzati igazgatásról szóló 2018. évi CXXV. törvény (a továbbiakban: Kit.) elfogadásáról, amelynek következményeként a kormányzati igazgatási szerveknél, azaz a Kormány alárendeltségében működő közigazgatási szerveknél foglalkoztatottak - egy évtizeden belül másodszor - új törvény hatálya alá kerültek..$^{20} \mathrm{~A}$ Kit. nyilvánvaló módon elköteleződött az egyre nyíltabbá váló közszolgálati személyzetpolitika mellett, ${ }^{21}$ hatálybalépésével pedig a Kttv. sorsa is megpecsételődött: előbb az önkormányzatoknál foglalkoztatott köztisztviselők, autonóm jogállású szervek, önálló szabályozó szervek köztisztviselőinek törvénye maradt, majd miután 2020. január 1-jén hatályba lépett a különleges jogállású szervekröl és az általuk foglalkoztatottak jogállásáról szóló 2019. évi CVII. törvényben (a továbbiakban: Küt.), a jogalkotó az utóbbi két kategória közszolgálati jogviszonyait is a Kit. szabályozási logikájához közelítette, ${ }^{22}$ a Kttv. szabályozási köre lényegét tekintve az önkormányzatoknál közszolgálati jogviszonyban állók körére szükült. ${ }^{23} \mathrm{~A}$ magyar közszolgálat bonyolult szabályozása kapcsán utalni szükséges arra, hogy 2021. január 1-jével hatályba lépett a Nemzeti Adó- és Vámhivatal személyi állományának jogállásáról szóló 2020. évi CXXX. törvény, amely speciális szabályokat írt elő az adó- és vámhatósági szolgálati jogviszonyra. Különös szabályok vonatkoznak továbbá a számvevői jogviszonyra az Állami Számvevőszékről szóló 2011. évi LXVI. törvény, az országgyűlési köztisztviselő közszolgálati jogviszonyára az Országgyülésről szóló 2012. évi XXXVI. törvény, a honvédelmi alkalmazottak szolgálati jogviszonyára a honvédelmi alkalmazottak jogállásáról szóló 2018. évi CXIV. törvény, valamint a rendvédelmi igazgatási alkalmazottak szolgálati jogviszonyára a rendvédelmi feladatokat ellátó szervek hivatásos állományának szolgálati jogviszonyáról szóló 2015. évi XLII. törvény (a továbbiakban: Hszt.) alapján. ${ }^{24}$

A közszolgálati jog „profiltisztítására” utaló jelek olvashatók ki a Kjt. hatályszüküléséből is. E körben említhető meg többek közt a felsőoktatási intézmények kiszervezésének folyamata a munka törvénykönyvéröl szóló 2012. évi I. törvény (a továbbiakban: Mt.) hatálya alá. A folyamat már 2019-ben megkezdődött, és napjainkban

${ }^{19}$ GYÖRGY István: Egységesség és differenciáltság a kormányzati szolgálati, közszolgálati és állami szolgálati jogviszonyban. In: Kiss György (szerk.): Közszolgálati életpályák jogi szabályozása. Dialóg Campus, Budapest, 2019, 106.

20 A Kit. ugyan 2019. január 1-jén lépett hatályba, de rendelkezéseinek jelentős részét csak 2019. március 1. napjától kellett alkalmazni. Megjegyzendő, hogy a Kit. értelmében 2019. december 31-ig a kormányhivatalok kormánytisztviselői részben speciális szabályozás hatálya alatt álltak (lásd Kit. 2019. december 31-ig hatályos Nyolcadik Részét).

${ }^{21}$ Lásd erről LUDÁNYI Dávid: Szemelvények a jogbiztonság változásairól a közszolgálati pragmatikában. Pro Publico Bono - Magyar Közigazgatás, 2019/4, 106-121.

22 A Küt. rendelkezéseit 2020. május 1-jétől kellett alkalmazni [Küt. 105. § (3) bekezdés].

${ }^{23}$ A közszolgálat egyre erősödő differenciálódásáról lásd LUDÁNYı Dávid: A közszolgálati jogviszony differenciálódása. Munkajog, 2020/1, 42-51.

${ }^{24}$ Lásd a rendvédelmi feladatokat ellátó szervek hivatásos állományának szolgálati jogviszonyáról szóló 2015. évi XLII. törvény és más kapcsolódó törvények módosításáról szóló 2018. évi CXV. törvényt. 
is tart. Ennek során az egykori közalkalmazotti jogviszonyok azáltal kerülnek az Mt. hatálya alá, hogy az egyetem állami fenntartású költségvetési szerv helyett alapítványi fenntartásba kerül át, így a változást követően a tág értelemben vett közszolgálatba tartozó közalkalmazotti jogviszony helyett mintegy „értelemszerűen” a versenyszféra munkajogi szabályainak hatálya terjed ki a foglalkoztatottakra. ${ }^{25}$

A közalkalmazotti jogállás „apasztása” egyes szektorokban akként is megvalósulhatott, hogy a közintézmények „privatizálásra” kerültek volna; így azok változatlanul állami, illetve önkormányzati fenntartásban maradtak, továbbra is ekként biztosítva a közszolgáltatásokat. Erre szolgáltatott példát a szakképzésről szóló 2019. évi LXXX. törvény, amely „kivonta” a szakképzést a köznevelés hatálya alól, egyszersmind a szakgimnázium és a szakközépiskola közalkalmazottjait a Kjt. jogállásváltozásra vonatkozó rendelkezései szerint az Mt. hatálya alá terelte (bár a Kjt. értelmében közalkalmazotti jogviszonyuk munkaviszonnyá átalakulását elutasíthatták). ${ }^{26} \mathrm{~A}$ kulturális intézményekben foglalkoztatottak közalkalmazotti jogviszonyának átalakulásáról, valamint egyes kulturális tárgyú törvények módosításáról szóló 2020. évi XXXII. törvény a levéltárakat, ${ }^{27}$ a múzeumokat, nyilvános könyvtárakat, közművelödési és integrált kulturális intézményeket ${ }^{28}$ valamint az előadó-múvészeti szervezeteket ${ }^{29}$ helyezte az Mt. hatálya alá. ${ }^{30}$ Azzal, hogy e törvények a munka közjogának hatálya alól a magánmunkajogba emelték át ezen intézményeket, azok mintegy „idegen testként" látják el az új jogszabályi környezetben a korábbi állami vagy önkormányzati közfunkcióikat. Nem önmagában a munkajog hatálya alá vonás itt a fö probléma, hanem az, hogy mindez pedig szükségszerüen és egyben indokolatlanul együtt jár az állami vagy önkormányzati „bekötésből” fakadó garanciák eliminálásával.

A differenciálódás erősödésével egyértelműen felgyorsult a magyar közszolgálat zárt közszolgálati rendszerektől való távolodása. E folyamatok egyúttal a munkajog szabályozási logikájától is egyre távolabb sodorják a közszolgálati jogot, és ily módon az említett jelenségek és szabályozási megoldások egyre erőteljesebben mutatnak a jogági elkülönülés irányába annak ellenére, hogy az adaptált jogintézmények ${ }^{31}$ sokszor a magánmunkajog eszköztárából származnak. Az így adaptált megoldások közjogias „kontextusba” helyezve, a kontraktuális módszereket számüzve sajátosan új minőséget hoznak létre a közszolgálati jogon belül.

\footnotetext{
${ }^{25}$ A Budapesti Corvinus Egyetem tekintetében 2019-ben, 2020-ban további hét egyetem vonatkozásában (köztük a Miskolci Egyetem tekintetében is) megvalósult a modellváltás. A 2021. április 30-án megjelent Magyar Közlönyben további tizenkét egyetem tekintetében - köztük a Debreceni Egyetem, a Szegedi Tudományegyetem és a Pécsi Tudományegyetem - regisztrálhattunk változást.

${ }^{26}$ Kjt. 25/A. § (5)-(6) bekezdés.

${ }^{27}$ A köziratokról, a közlevéltárakról és a magánlevéltári anyag védelméröl szóló 1995. évi LXVI. törvény.

${ }^{28}$ A muzeális intézményekről, a nyilvános könyvtári ellátásról és a közművelődésről szóló 1997. évi CXL. törvény.

${ }^{29}$ Az előadó-művészeti szervezetek támogatásáról és sajátos foglalkoztatási szabályairól szóló 2008. évi XCIX. törvény.

${ }^{30}$ Ezt a folyamatot részletesen elemzi MÉlYPATAKI-PRUgberger: i. m., 16-17.

${ }^{31}$ Például a versenyszféra teljesítményértékelésének alkalmazása a munkáltatónak egyoldalú módosítási lehetőséget biztosít a kinevezésben - egy megállapodásban - kikötött illetmény módosítására. Lásd továbbá a Kit.-ben az elhelyezkedési korlátozás (Kit. 117. §) szabályai, amely lényegét tekintve a versenytilalmi megállapodás közszolgálati megfelelője (igaz, megállapodás nélkül), vagy a feladatok hatékonyabb ellátásának biztosítása mint felmentési ok (Kit. 108. §), amely lényegében a minőségi csere megfelelője.
} 


\section{Szemelvények a közszolgálati jogi szabályozás jellemzői köréből}

A hivatkozott tanulmányban felsorakoztatott érvek közül érdemes ehelyütt felidézni a közszolgálati jogviszonyok szerződéses megalapozását alátámasztó álláspontot is. ${ }^{32}$ A közszolgálati jogviszonyokat - ellentétben például a Kttv. Általános indokolásában vázoltakkal - nem az állam egyoldalú aktusa, hanem a felek megállapodása hozza létre. Ezt a megállapítást tükrözi a tételes jogi szabályozás is. A jogviszony ugyanis a kinevezéssel és annak elfogadásával, vagyis a felek kölcsönös és egybehangzó jognyilatkozatával jön létre ${ }^{33}$ Ezen túlmenően nem tekinthetö közömbösnek az sem, hogy a közszolgálati jogszabályok - így például Kttv. II. fejezete és a Kit. XI. fejezete is - egyértelmüen a kötelmi jog alapvető megoldásait alkalmazza, lényegében az Mt. és a Polgári Törvénykönyvröl szóló 2013. évi V. törvény dogmatikai készletével azonos módon, ezzel is bizonyítékot szolgáltatva a civil közszolgálat szerződéses megalapozására. ${ }^{34}$ Hozzá kell ugyanakkor tenni: a kinevezés tartalommegállapító funkciója kétségkívül jelentős részben formális, az csak az egyes jogállási törvényekben rögzített kötelező tartalmi elemeket duplikálja, így javarészt jogviszony-létesítő, illetve szimbolikus funkciót tölt be. ${ }^{35}$

Itt kell említést tenni arról a sajátos jelenségröl is, amely a magyar közszolgálati jogi szabályozás legújabb fejleményeit jellemzi. Megítélésünk szerint egyre inkább meghatározóvá vált két egymásnak némileg ellentmondó jogalkotói attitúd megjelenése a közszolgálati jogi jogalkotásban. Az instrumentálisnak („eszköz-szemléletünek”) nevezhető felfogás az „erős állam” koncepciójából indul ki. Ez a közszolgálati alkalmazott közjogi jogállását helyezi előtérbe, és az államnak való alávetettségét

${ }^{32}$ KUN-Petrovics: i. m., 3-4. E körben utalni szükséges arra, hogy e konstrukció a magyar jogban sem új keletủ: már Magyary Zoltánnál is megjelenik a közhivatalnok magánjogi alapokon nyugvó, azaz lényegét tekintve szerződéses foglalkoztatása a másodlagos közszolgálati jogviszonyban állók, valamint a közigazgatással kapcsolatos mellékszolgálatok esetében. Mindez bizonyítja azt, hogy a közjogi gondolkodástól sem volt idegen a jogviszonyok szerződéses megalapozásának gondolata (lásd MAGYARY Zoltán: Magyar közigazgatás. Budapest, Királyi Magyar Egyetemi Nyomda, 1942. 377-378.).

${ }^{33}$ Kttv. 38. § (1) bekezdés, LeHoczkynÉ KollonAY Csilla: A munkaszerződés megkötése. In: Lehoczkyné Kollonay Csilla (szerk.): A magyar munkajog I. Vince, Budapest, 2000, 97., PRUGBeRger Tamás: Munkajog a polgári jogban a globalizálódó gazdasági viszonyok között. Bíbor, hely és évszám nélkül, 19., RAB Henriett: A közszolgálati különbíráskodás HR-szempontú vizsgálata. Közjogi Szemle, 2016/1, 9.

${ }^{34}$ Itt érdemes megemlíteni, hogy a nemzetközi kitekintés alapján a közszolgálat szerződéses megalapozása számos államban elfogadott [lásd például Svédországot: NÉMETHY Sándor-NEMESKÉRı Zsolt: Svédország közigazgatási emberi erőforrás menedzsment tudásmegosztásának és a HR szakemberek fejlesztési módjainak vizsgálata. In: Szakács Gábor-Csóka Gabriella (szerk.): A közigazgatási emberi erőforrás menedzsment tudásmegosztása és a HR szakemberek fejlesztése nemzetközi gyakorlatának vizsgálata. Nemzeti Közszolgálati Egyetem, Budapest, 2018, 213.], illetve ezen túlmenően egyre inkább elöretörni látszik. Hollandiában például 2014 után lényegében megszűnt a magánszféra és a közszféra foglalkoztatásbeli különállása (lásd MÉLYPATAKI-PRUgBERgER: i. m., 16-17.), Portugáliában a reformtörekvések eredményeként 2014-re a közszolgálati alkalmazottak státusza összességében több tekintetben közeledett a versenyszféra foglalkoztatási jogviszonyaihoz, amint megjelent a munkaszerződéssel történő alkalmazás [lásd ARAúJo, Joaquim Filipe Ferraz Esteves de: Administrative Reform in Portugal: a brief state of the art. NEAPP (Núcleo de Estudos em Administração e Políticas Públicas, Universidade do Minho, Escola de Economia e Gestão) 4. https://soc.kuleuven.be/io/cost/act/paper/Araujo_Portugal_2007.pdf (2021. 08. 23.)].

${ }^{35}$ Kun Attila: A közszolgálati jogviszonyt keletkeztető jogi tények - kinevezés kontra szerződés. Pro Publico Bono - Magyar közigazgatás, 2018/2, 84-85. 
hangsúlyozza. ${ }^{36} \mathrm{Az}$ egyoldalú kinevezésmódosítás - alábbiakban röviden elemzett koncepciója - nyilvánvaló módon ennek az egyik lenyomata. A másik koncepció egyfajta humánus, emberközpontú megközelítést helyez a középpontba, ami a közszolgálati alkalmazott személyére, méltánylást érdemlő érdekeire, védelmet igénylő helyzetére koncentrál. Erre a megszüntetés rendszerében példa lehet a felmentési tilalmak Mt.-hez képest szélesebb körü szabályozása vagy a családbarát szemlélet erősödése a Kit. rendelkezései között. ${ }^{37}$

A közszolgálati jogi szabályozás részben fentiekben írottakkal is összefüggő sajátos megoldása a kinevezés munkáltatói jogkör gyakorlója általi egyoldalú módosításának lehetősége. Ez a magyar közszolgálatban újszerü megoldás kétségkívül távolítja a közszolgálati jogot a munkajogi szabályozás logikájától, egyszersmind zárójelbe teszi a korábbiakban felvetett szerződéses megalapozást. Ugyanakkor ezt a megoldást - és vele az említett "távolítást” - több szempontból is aggályosnak tekinthetjük, mind dogmatikai, mind pragmatikus okokól. A kinevezés egyoldalú módosítása a Kttv.-ben és a Küt.-ben ugyan széles körben alkalmazható, ám elviekben kivételes jogintézményként jelenik meg, ${ }^{38}$ a Kit.-ben azonban általános szabállyá lépett elő. ${ }^{39} \mathrm{Az}$ egyoldalú kinevezésmódosítás elutasítására a Kttv.-ben és a Küt.-ben csak szük körben, valójában a jogviszony felmentéssel történő megszüntetése árán van lehetőség. A Kttv. szerint, amennyiben a köztisztviselő nem kíván a munkáltató által egyoldalúan módosított kinevezés szerinti munkakörben dolgozni, a kinevezésmódosítástól számított négy munkanapon belül írásban kérheti a felmentését, ha a kinevezésmódosítás után az új illetménye nem éri el a korábbi illetménye összegének $80 \%$-át, vagy amennyiben az egyoldalú kinevezésmódosítás eredményeként korábbi vezetői munkakörét nem vezetői munkakör váltotta fel. A Küt.-ben e szabályokat egészíti ki a munkaidő megváltozása is. ${ }^{40} \mathrm{~A}$ Kit. alapján a kormánytisztviselő hét esetben kérheti a felmentését a kinevezés módosításának közlésétől számított négy munkanapon belül. Ilyen például a már említett mértékủ illetménycsökkentés mellett a munkaidő megváltozása, a munkavégzés helyének a település határán kívülire módosítása, az iskolai végzettségnek, szakképzettségnek vagy szakképesítésnek, szakmai tapasztalatnak meg nem felelő feladatok ellátására kötelezés vagy a szakmai vezetői álláshelyen foglalkoztatott kormánytisztviselő ügyintézői álláshelyre helyezése. ${ }^{41}$

A jogintézmény nem zárja ki azt, hogy a munkáltató arra használja fel, hogy a köztisztviselőt vagy a kormánytisztviselőt olyan helyzetbe hozza az indokolási kötelezettséghez nem kötött egyoldalú kinevezésmódosítással, amely alapján az nem látva más „kiutat”, a felmentését kérje..$^{42}$ Olybá tűnik, a szabályozás ezen a ponton a

\footnotetext{
${ }^{36}$ Kun Attila: A közszolgálati jogviszony alanyai, különös tekintettel a tisztviselő jogállására. Pro Publico Bono - Magyar közigazgatás, 2017/4, 101-102.

${ }^{37}$ Kit. XX. fejezet.

${ }^{38}$ Kttv. 63. $\S(2)$ bekezdés $d$ ) pont, 48. $\S(2)$ bekezdés $\left.d\right)$ pont, 58. $\S(6)$ bekezdés, Küt. 29. $\S(2)$ bekezdés, (7) bekezdés, 39. $\S(3)$ bekezdés e) pont.

${ }^{39}$ Kit. 89. §.

40 Küt. 29. $\S(7)$ bekezdés $c)$ pont.

${ }^{41}$ Kit. 89. § (3) bekezdés.

42 KÁRTYÁs Gábor: Sine systema chaos. A Kttv. módosításának rendszertani kritikája. HR \& Munkajog, 2015/7-8, 27.
} 
szolgálatvállalóra mint az állami feladatellátás eszközére tekint. Könnyen elképzelhető továbbá, hogy a munkáltató szándékosan olyan módon módosítja egyoldalúan a kinevezést, hogy már előzetesen nagy valószínüséggel tudja, azt a másik fél nem fogja „elfogadni”, s ezért kérni fogja majd a felmentését. Szemléletesen erre tekintettel nevezhetjük e jogintézményt a „felmentés előszobájának”. ${ }^{43}$

\section{Az igényérvényesítést érintő változások}

Kétségtelen, a közszolgálati jog és a versenyszféra munkajogának bírói gyakorlata a magyar jogalkalmazásban gyakorlatilag egybefonódott. ${ }^{44}$ Amint arra a Kúria Kormánytisztviselői Döntőbizottság-határozatok bírósági felülvizsgálatával foglalkozó joggyakorlat-elemző csoportjának összefoglaló véleménye rámutat, a Kormánytisztviselői Döntőbizottság ${ }^{45}$ ugyancsak hagyatkozik a hosszabb idő óta egységes munkajogi ítélkezési gyakorlatra, határozatainak indokolásában pedig rendszeresen hivatkozik az egykori Legfelsőbb Bíróság Munkaügyi Kollégiumának állásfoglalásaira is. E tapasztalatok is azt mutatják, hogy a foglalkoztatási jogviszonyokból eredő jogviták elbírálásának egységes logikája a Kormánytisztviselői Döntőbizottság eljárásának bevezetésével sem feltétlenül tört meg. Amint azt a Kúria joggyakorlatelemző csoportja kiemeli, eltérő jogi szemlélettel valószínüleg értelmezhetetlenek lennének a „közszolgálat munkajogának” egyes fogalmai, így a Kttv. - és hozzátehetö, a többi jogállási törvény - rendelkezéseinek helyes értelmezése megköveteli a közszolgálati jogi ismereteken felül az elmélyült munkajogi tudást, és azon belül a munkajogi ítélkezési gyakorlat, valamint a közös munkajogi és közszolgálati jogi „alapelvek" ismeretét. ${ }^{46}$

Kérdéses ugyanakkor, hogy a jövőben ez a tendencia megmarad-e, ugyanis a tág értelemben vett közszolgálati jogviszonyok egy jelentős részével összefüggő perek, valamint a munkaviszonnyal kapcsolatos perek elbírálása szervezetileg is különvált. 2020. március 31. napjával ugyanis megszüntek a közigazgatási és munkaügyi bíróságok, ${ }^{47}$ így 2020. április 1 -jétöl első fokon munkaügyi perekben a törvényszékek járnak el, a közszolgálati jogviszonnyal kapcsolatos perekben pedig regionális illetékességgel nyolc törvényszék bírálja el a jogvitákat.

A két terület „perjogi szétválasztásával” összefüggő lépések már a közigazgatási és munkaügyi bíróságok megszűnését megelőzően megkezdődtek. A munkaügyi

${ }^{43}$ HORVÁTH István: Közszolgálat: komparatív elönyök - hátrányokkal. Munkajog, 2017/1, 20.

${ }^{44}$ KUn-Petrovics: i. m., 33.

45 2017. november 19-étöl a testület elnevezése: Közszolgálati Döntőbizottság. A Kormánytisztviselői Döntőbizottság elnevezésének megváltoztatásával összefüggő egyes törvények módosításáról szóló 2017. évi CXXXIX. törvény a Kormánytisztviselöi Döntőbizottság nevét Közszolgálati Döntőbizottságra módosította.

${ }^{46}$ A Kormánytisztviselöi Döntöbizottság határozatai bírósági felülvizsgálata. Összefoglaló vélemény. 2015. 14-15. https://kuria-birosag.hu/sites/default/files/joggyak/kdb_hatarozatai_birosagi_felulvizsgalata_osszefoglalo_ velemeny.pdf (2021. 05. 26.).

${ }^{47}$ Lásd az egyes törvényeknek az egyfokú járási hivatali eljárások megteremtésével összefüggő módosításáról szóló 2019. évi CXXVII. törvényt. A munkaügyi bíráskodásról és közigazgatási és munkaügyi bíróságok megszünésének értékeléséről lásd LőRINCz György: In memoriam munkaügyi bíróság (szubjektív emlékezés). Munkajog, 2020/2, 1-4. 
bíráskodás fórumrendszere előbb elnevezésbeli, illetve szervezeti változáson esett át (munkaügyi bíróságok helyébe 2013. január 1-jétöl közigazgatási és munkaügyi bíróságok léptek), majd a polgári perrendtartás reformja, illetve a közigazgatási rendtartás kodifikációs munkái során már felmerült a munkaügyi bíróságok mint különbíróságok felszámolásának gondolata, ${ }^{48}$ valamint a közszolgálati jogviták közigazgatási bíráskodásra utalásával a munkaügyi bíróságok hatáskörének szükítése.

A közigazgatási perrendtartás koncepciójának előkészítéséről szóló munkaanyag arra az álláspontra helyezkedett, hogy a közszolgálati jog a közigazgatási jog része..$^{49} \mathrm{Az}$ érvelés szerint, mivel a munkáltatók közigazgatási szervek, valamint közhatalmi jogkörökkel felruházott jogalanyok, a kinevezés egyoldalú aktus, a közszolgálati jogvitákat pedig a közigazgatási és elsősorban szervezeti jogi kérdések túlsúlya jellemzi, azokra a munkaügyi per szabályai helyett a közigazgatási perek szabályait indokolt alkalmazni. ${ }^{50} \mathrm{Az}$ e megközelítést alátámasztó indokokat a koncepció közelebbröl nem fejtette ki, holott a felsorolt állítások elfogadottsága a hazai szakirodalomban korántsem egyértelmű. A koncepció által hivatkozott alkotmánybírósági érvelés, amelynek értelmében a közszolgálat jogviszonyai alapvetően közjogi jellegủ jogviszonyok, önmagában még nem zárja ki, hogy azokat a munkaügyi perekre irányadó szabályok szerint bírálják el.

Amint arra utaltunk, a közigazgatási perrendtartás előkészítéséről szóló munkaanyag szerint „,a közszolgálati jogvitákban felmerülö közigazgatási (elsősorban szervezeti) jogi kérdések túlsúlya is indokolttá teszi e területnek a munkaügyi per szabályai helyett a közigazgatási perek szabályai szerinti elbírálását”. ${ }^{51} \mathrm{E}$ megállapítással ellentétben megítélésünk szerint a közszolgálati jogvitákban valójában nem közigazgatási jogi, hanem érdemét tekintve munkajogi tárgyú kérdések vetődnek fel. Ezekben a perekben érdemben nem vagy nem gyakran merülnek fel közigazgatási jogi kérdések, ezért nem szükséges a közigazgatási eljárás magasabb szintü ismerete, e jogviták tárgya ugyanis a foglakoztatás tartalmának vizsgálatára irányul. ${ }^{52}$

A fentiekkel kapcsolatosan szükséges utalni röviden a Kúria közigazgatási perjogot vizsgáló joggyakorlat-elemző csoportjának összefoglaló véleményében foglaltakra. A véleményből az tünik ki, hogy a joggyakorlat-elemző csoport munkaügyi

${ }^{48}$ A Munkaügyi Bírák Országos Egyesületének Elnökségének 2016. szeptember 2-i közleménye a munkaügyi bíráskodás felszámolásának tervét elhibázottnak, az európai jogállamisági elvekkel és gyakorlattal ellentétesnek tartotta, és úgy vélekedett, hogy az súlyosan veszélyeztetné a jogegységet [lásd Közigazgatási bíráskodás dosszié: Felszámolják a munkaügyi bíráskodást? A Munkaügyi Bírák Országos Egyesületének Elnökségének közleménye. http://ugyvedforum.hu/cikkek/2016/10/kozigazgatasi-biraskodas-dosszie (2021. 05. 26.)].

${ }^{49}$ Tény, hogy a közigazgatási jog a második világháborút megelőzően a közszolgálat személyi állományába tartozókra vonatkozó joganyagot a közjog szabályai alá sorolta, illetve a közigazgatási jog részének tekintette. Lásd például MAGYARY: i. m. Ezen túlmenően megjegyzendő, hogy a közigazgatási jog hagyományosan foglalkozik a közszolgálat személyi állományának kérdéseivel.

${ }^{50}$ Részletes jelentés a közigazgatási perrendtartás koncepciójának elökészítéséről. Munkaanyag. 2015. 11. https://docplayer.hu/7513437-Reszletes-jelentes-a-kozigazgatasi-perrendtartas-koncepciojanakelokesziteserol-i-elozmenyek.html (2021. 05. 26.).

${ }^{51}$ Részletes jelentés a közigazgatási perrendtartás koncepciójának elökészítéséről. Munkaanyag. 2015. 11.

${ }^{52}$ RAB: i. m., 9. Lásd továbbá még PRUGBERgER Tamás: Adalékok a munkaügyi bírósági szervezet és eljárás tervezett átalakításához. HR \& Munkajog, 2015/5, 31-34., MÉLYPATAKı Gábor: A munkaügyi bíráskodás jelenéről és jövőjéről. HR \& Munkajog, 2015/7-8, 35-37. 
szakágat képviselő tagja határozott álláspontot képviselt a közszolgálati jogviták hatásköri szabályozásával kapcsolatban. Az általa előadottak szerint - amit magunk is osztunk - a közszolgálati jog a munkajog speciális jogterülete, „amely nem annyira a szabályozott életviszonyok eltérősége miatt különül el, hanem a munkavégzést, mint 'szolgáltatást' fogadó fél, a munkáltató személye miatt, tekintettel arra, hogy azok a közhatalom birtokában vannak". Ebből következően álláspontja szerint sem indokolt eltérő peres eljárási szabályok alkalmazása, és mindez nem adhat kellő alapot a közszolgálati jogviták közigazgatási per kereteibe történő beillesztésére..$^{53}$

Amint a Munkaügyi Bírák Országos Egyesülete Elnökségének 2016. szeptember 2-i közleménye fogalmazott, „a teljes jogászi szakma - beleértve a közigazgatási birákat is - egyetértett abban, hogy a közszolgálati jogviták munkaügyi jogviták, munkaügyi perben kell ezeket elbírálni. Ennek ellenére a közigazgatási perrendtartás tervezetében a közigazgatási ügyek között kerültek elhelyezésre, megfosztva az ügyfeleket attól, hogy jogvitájukat munkaügyi szakbíró bírálja el a munkaügyi perekre vonatkozó sajátos eljárási szabályok mellett. Nem vitás, hogy a közszolgálati jogviszonyokban sok a közjogi elem, de ez - bár kisebb mértékben - a munkaviszonyra is jellemző, hiszen a felek egyenlötlen helyzetét a kötelező törvényi szabályokkal lehet kiegyensúlyozni." ${ }^{4}$

A közszolgálati jogviszonyok jelentős részével összefüggő perek, valamint a munkaviszonnyal kapcsolatos perek elbírálásának elkülönülése ugyanakkor lényegét tekintve nem a közigazgatási és munkaügyi bíróságok megszünésével következett be. A különválás gyakorlatilag már 2018. január 1-jén, a közigazgatási perrendtartásról szóló 2017. évi I. törvény (a továbbiakban: Kp.) és a polgári perrendtartásról szóló 2016. évi CXXX. törvény (a továbbiakban: Pp.) hatálybalépésének időpontjában bekövetkezett. A jogalkotó - a fentebb is ismertetett érvek ellenére - a magánmunkajogi és a közszolgálati jogi jogviták elbírálásának szervezetét és eljárási szabályait ugyanis a 2010-es évek végére átalakította. Elsőként a 2018. január 1-jétöl hatályos $\mathrm{Kp}$. leválasztotta a közszolgálati jogviszonnyal kapcsolatos pereket a munkaügyi perekröl. A munkaügyi perek a Pp., a közszolgálati jogviszonnyal kapcsolatos perek a Kp. rendelkezései szerint folynak..$^{55} \mathrm{~A} \mathrm{Kp}$. ugyanakkor nem sorolja fel kimerítő jelleggel a hatálya alá tartozó valamennyi, általa közszolgálati jogviszonynak tekintett jogviszonyt. A Kp. értelmében közszolgálati jogviszonynak minősül valamennyi, az állam vagy az állam nevében eljáró szerv és az általa foglalkoztatott személy között munkavégzés, illetve szolgálatteljesítés céljából létesített, a köz szolgálatára irányuló, törvényben meghatározott speciális kötelezettségeket és jogokat tartalmazó jogviszony. ${ }^{56}$ Megállapítható, hogy míg a Kttv., a Kit., a Hszt. és a honvédek jogállásáról szóló 2012. évi CCV. törvény szerinti jogviszonyok e körbe sorolhatók, a Kp. kifejezett kizáró szabálya alapján a bírák jogállásáról és javadalmazásáról szóló 2011. évi

\footnotetext{
${ }^{53}$ Kúria Közigazgatási-Munkaügyi Kollégium Közigazgatási joggyakorlat-elemző csoport: A közigazgatási perjog. Összefoglaló vélemény. 2014.El.II.F.1/7. Budapest, 2014. 28. https//.kuria-birosag.hu/sites/default/files/ joggyak/kozigazgatasi_perjog.pdf (2021. 05. 26.).

${ }^{54}$ Lásd Közigazgatási biráskodás dosszié: Felszámolják a munkaügyi bíráskodást? A Munkaügyi Bírák Országos Egyesületének Elnökségének közleménye.

${ }^{55} \mathrm{Kp} .5$. § (4) bekezdés.

${ }^{56} \mathrm{Kp} .4$. $\S(7)$ bekezdés 3. pont.
} 
CLXII. törvény, az igazságügyi alkalmazottak szolgálati jogviszonyáról szóló 1997. évi LXVIII. törvény, a legföbb ügyész, az ügyészek és más ügyészségi alkalmazottak jogállásáról és az ügyészi életpályáról szóló 2011. évi CLXIV. törvény hatálya alá tartozó jogviszonyokból, a közalkalmazotti jogviszonyból ${ }^{57}$ és a közigazgatási szervnél foglalkoztatott munkavállalók munkaviszonyából származó jogviták azonban a Pp. által szabályozott munkaügyi perek körébe tartoznak. ${ }^{58}$ Megítélésünk szerint ez a logika egyáltalán nem tekinthetö következetesnek. Különösen a közszolgálati jogviszonyból származó jogviták elkülönült szabályozása melletti érvek tükrében nem világos, hogy milyen elvi megfontolások tették szükségessé mégis ezt a megosztottságot, a közszolgálat területéhez tartozó jogviszonyok ily módon történő megosztására a jogalkotó - legalábbis véleményünk szerint - nem ad észszerủ magyarázatot.

Mivel a jogágak általában külön jogalkalmazási eljárás során realizálódnak, különös jelentősége volt annak, hogy a közszolgálat és a munkajog bírói gyakorlata eleddig nem különült el élesen, egymást szervesen kiegészítette, és egyfajta kölcsönös hézagpótló funkcióval is bírt. ${ }^{59}$ Megítélésünk szerint - különösképpen a publikált döntések csekély számára tekintettel - egyelöre nehezen lehetne felmérni azt, hogy a 2018 óta bekövetkezett „eljárásjogi szétválás” pontosan milyen mértékben erősítette a jogági elkülönülést. Mindazonáltal nagy valószínűséggel feltételezhető, hogy idővel a bírói gyakorlat - adott esetben még az azonos gyökerü jogintézmények esetében is - egyre inkább széttartóvá válik, az eljárásjogi törvények eltérő rendelkezései nyomán pedig önálló logika mentén folytatódhat a közszolgálati jogi és a munkajogi jogintézmények fejlődése. Az már most is jól látható, hogy mindezt kiegészíti, hogy az Mt. és a különböző közszolgálati törvények rendelkezései számos esetben eltávolodni látszanak egymástól (lásd például az Mt. és a Kit. megoldását a szabadságra való jogosultságot illetően), ennélfogva e tartalmi változások következtében az ítélkezési gyakorlat elvi jelentőségủ megállapításai a jövőben minden bizonnyal csak jóval differenciáltabban alkalmazhatók kölcsönösen. Az igényérvényesítés eltérő útjai, a peres eljárások markáns eltérései összességében jelentős hatást gyakorolnak az alkalmazott oldalán az igényérvényesítés hatékonyságára, és egyben erősítik a jogági elkülönülés tendenciáit. Mindebből következően egyet kell értenünk Mélypataki Gáborral és Prugberger Tamással, akik szerint a közszolgálati jog és a munkajog szétválasztásában az „eljárásjogi elkülönülés” - a munkaügyi és a közszolgálati jogviták kettéválasztása - döntő jelentőséggel bír. ${ }^{60}$

\section{Következtetések}

Az, hogy a tanulmányunk elején hivatkozott tanulmány következtetései a közszolgálati jog és a munkajog együvé tartozását illetően mennyiben megalapozottak,

\footnotetext{
${ }^{57} \mathrm{Pp} .508 . \S(1)$ bekezdés b) pont.

${ }^{58}$ Kp. 4. $\S(7)$ bekezdés 3. pont; Pp. 508. § (1) bekezdés b) pont. Lásd Petrovics Zoltán: A közszolgálati jogviszony alanyai, különös tekintettel a szolgálatadó (munkáltató) jogállására. Pro Publico Bono - Magyar Közigazgatás, 2017/3, 57-58.

${ }^{60}$ MÉLyPATAKI-Prugberger: i. m., 15.
}

$132{ }^{59}$ Kun-PETROVICS: i. m., 17. 
nyilvánvaló módon újra és újra felvethető. Amint látható volt, az utóbbi időszak jogalkotási fejleményeinek egy jelentős része hazánkban markánsan a közszolgálati jog önállósága irányába mutat. Ugyanakkor figyelemre méltó és „beszédes”, hogy egyrészt e reformok szinte mindenkor a versenyszféra és vele a munkajog viszonylatában - „ahhoz képest”, „ahhoz viszonyítva” - kerülnek artikulálásra (például kimutatható számos tartalmi „közeledés” is a munkajoghoz a közszolgálati jog szövetében, a leválasztás hivatalos iránya ellenére ${ }^{61}$ ). Másrészt a reformok egy része (például egyes közalkalmazotti jogviszonyok „kiszervezése” a munkajogba; a Kit.-ben a munkaviszonyban történő foglalkoztatás relatíve megengedő szabályai) azt mutatja, hogy elviekben maga a jogalkotó is elismeri, hogy a tágabb értelemben vett közszolgálattól tulajdonképpen nem feltétlenül idegen a - bizonyos elemeiben persze sajátos - munkajogi megoldás. ${ }^{62}$ Mindez egyébként a nemzetközi trendekkel is egybevág(na). Ahogyan azt egy 2018-as összehasonlító európai uniós kutatás megjegyzi, a tagállamokban a munkaszerződés szerinti közszolgálati foglalkoztatás aránya egyértelmüen növekszik, sőt az EU-országok többségében azt is megfigyelhetjük, hogy a (közjogi) köztisztviselők és a (munkajogi státusú) közszolgálati alkalmazottak közötti különbségek csökkennek (tekintve e két foglalkoztatási forma jogainak és kötelességeinek, munkakörülményeinek részletesebb elemzését). Mindez azt üzeni, hogy érdemes lehet a címkéken túltekinteni, és a szabályozás tartalmára fókuszálni. ${ }^{63}$

Összességében kijelenthető, hogy a közszolgálati jogot illetően a folyamatos mozgás jellemző. A mozgást kísérő jelenségek ugyan a közszolgálati jog sajátosságain nem változtatnak, éppen ezért álláspontunk szerint önmagában e jelenségek miatt nem indokolt módosítani a kiindulópontul szolgáló megállapításon, vagyis a közszolgálati jogot továbbra is a munkajogon belül, annak egyik viszonylagos önállósággal bíró területeként indokolt elhelyezni. Ezzel együtt azonban nem lehet elsiklani afelett, hogy a közszolgálati jog egyre inkább de facto önállóságra tör, egyre több olyan jogi megoldást alkalmaz, amely a munkajogi logikával kifejezetten ellentétes (lásd például a kinevezés egyoldalú módosításának általános szabályát). Mindezek alapján nehéz lenne megjósolni, hogy hol lehet a folyamat vége. Arra következtetünk azonban, hogy abban a kérdésben, miszerint a közszolgálati jog valóban teljes mértékben képes lesz-e önállósulni, és szakítani a munkajoggal, a választ megítélésünk szerint nem szerves, „belső” fejlődés eredményeként levont következtetés alapján adhatjuk meg (noha annak értelmében a nemleges válasz tűnik indokoltnak). Mindezt ugyanakkor a jogalkotói törekvések által kiváltott fejlemények mindenkor árnyalhatják, illetve végső soron eldöntik.

${ }^{61}$ Lásd például a Kit.-ben: szabadság, munkaközi szünet, díjazás „versenyképességének” igénye, nem kötelező teljesítményértékelés stb.

62 Különösen érdekes az a jelenség (még akkor is, ha vélhetően jogalkotói „elírás”), amikor maga a közszolgálati törvény (például a Kit.) munkaviszonyról beszél (kormányzati szolgálati jogviszony helyett). Lásd például a Kit. 172. § (6) bekezdését, amelynek értelmében a szakszervezet jogosult a kormánytisztviselőket a munkaügyi kapcsolatokkal vagy a munkaviszonnyal összefüggő kérdésekben tájékoztatni.

63 ThIJS, Nick-HAMmERSCHMID Gerhard-PALARIC, Enora: A comparative overview of public administration characteristics and performance in the EU28. Publications Office of the European Union, Luxembourg, 2018, 23-24. 